\title{
Influence Of Government Regulated On Performance Business By Entrepreneur Orientation And Environment Adaptability Small Medium Enterprice Chips Industry
}

\author{
Samiadji ${ }^{1}$, Anwar Sanusi ${ }^{2}$, Abdul Manan ${ }^{3}$ \\ ${ }^{1}$ Doctoral Student in economic, Merdeka University of Malang, Indonesia \\ ${ }^{2,3}$ Faculty of Economics and Business, Merdeka University of Malang, Indonesia
}

\begin{abstract}
This research has the general aim to examine empirically and to analyze the effect of government regulation on business performance through entrepreneurial orientation and environment adaptability. The specific goals of this research are : (1) to examine empirically the effect of the government regulation on entrepreneur orientation and environmental adaptation; (2) to examine the effect of government regulation on the business progress ; (3) to examine the effect of the government regulation on the business progress by entrepreneur and environmental adaptability. The research takes place in East Java are in Malang municipality, Lumajang county, Pasuruan county, and Trenggalek county amount 394 business units. Collecting data in this study was done by using proportional random sampling technique of 198 business units. The data analysis use she structural Equation Modeling. The result of this research showed that: (1) The government regulation has no effect to improve progress, and only had significant effect through entrepreneurial orientation,. (2) The government regulation has no significant effect to increase business progress, and only had significant effect by environmental adaptation, (3) The government regulation could increase the business progress of the underlined chip business in East Java by entrepreneurial orientation and environmental adaptability.
\end{abstract}

Keywords: Government regulation, entrepreneurial orientation, environmental adaptability, business performance.

\section{Introduction}

The existence of the weak entrepreneurs in Indonesia that organized by the Ministry of Industry and Trade of the Republic of Indonesia showed that all business units in various sectors of the economy amounted to very much. According to BPS data (2012) is almost entirely dominated by the economically weak effort that is equal to $99.76 \%$, only $0.14 \%$ medium-sized businesses and the remaining $0.01 \%$ is a big effort. Natural potential in East Java province, abundant, and diverse agricultural and plantation has become an icon for each region. Base by this fact, the researchers would like to help give a thought to develop Entreprices Small Business (SME's) chips industry in East Java, Indonesia. Indonesia as a developing country is very appropriate if SME's nurtured and is grown as one of the pillars of the economy. SME's is a form of entrepreneurship that span the entire business activities of both large and small, and the type of industry that is able to "survive" in times of economic crisis. However, the development of SME's in Developing Countries, including Indonesia face many obstacles. The results of the study Tambunan (2012) found that the barrier or obstacle SME's is the limited working capital, investment, difficulties in marketing, distribution, procurement of raw materials, limited access to information on market opportunities, limited skilled workers (the quality of human resource is low), the ability of technology, communication limitations, high costs of administrative procedures and bureaucracy as complex as business licenses and regulatory uncertainty and economic policies that are not clear or undirected.

Taking into account the results of the study SME's in Indonesia, it is evident that the development of SME's in Indonesia has not shown superior performance. Lack of SME's adapt to consumer demand makes the SME's are not responsive to the willingness of the market. Governments have an obligation to solve three classical problems that often befall SME's, such as access to markets, capital and technology that has become the talk at seminars and conferences. Government policies and regulations are still not maximized. The fact indicated that government policies tend to be excessive and ineffective, so the policy becomes less comprehensive, yet focused, as well as confusing.

The results of the study Hidayatullah (2011) showed that the factor of adaptability as an intangible resource has a positive role in promoting entrepreneurship and innovation orientation, but not directly contribute positively to business performance. Chain of research results (2011) showed that four variables consisting of organizational culture, the role of government, entrepreneurship and performance, indicating that entrepreneurship has an important role as mediation of organizational culture and the role of government to improve the performance of SME's. This study aims to: (1) Describing the effects of government policy on 
environmental adaptability SME's chips. (2) Describe the effect of government policies on the performance of enterprises SME's chips. (3) Describe the effect of government policies on the performance of the business through entrepreneurial orientation SME's chips. (4) and Explaining the effects of government policy on business performance through environmental adaptability SME's chips.

\section{Business Performance}

\section{Literature Review}

Business performance is a display state as a whole over the company for a certain period, which is the result or achievement is affected by the operations of the company in utilizing the resources owned Helfert (1996). More specifically Lawler and Porter (1997) which stated that the performance is a person's success in performing the task. Measurenment of succes in organization includes sales growth, market share and competitive size Jacobson (1996).

\section{Government Policy}

Act 20 of 2008, regulates the SME's, the government has mandated expressly in order to facilitate the empowerment of SME's in the areas of capital and equipment, production and processing, marketing, human resources as well as design and technology. Farel (1992), stated that the process of providing government assistance can affect the improvement of the efficiency of the production process is the process of policies (the policies process) is carried out by a person in combining capital resources, conduct market expansion, increasing the number and variety of products and to determine the level of wages . Kroon and Moolman (1992), stated that the training program can help owners / managers to learn how to approach on certain issues and in this way will save you time and money, as well as aware of the rules and certain procedures that can help them to do so. Westhead and Storey (1996) suggested a link between the implementation of management training programs and level of performance of small businesses in measuring survival, profit and sales growth rate. According Laceiva (2004), the determinants of SME's success consists of internal and external factors. Internal factors determining success are: (a) financial management (b) the management company (c) raw materials, mechanical and business location (d) production process (e) the amount offered in the market (f) management personnel; External Determinants of success are: (a) government policy (b) The market situation (c) Availability of funds (d) Information (e) infrastructure.

\section{Entrepreneurial Orientation}

Lumpkin and Dess (1996) define entrepreneurial orientation as a decision-making style, processes and methods that inform the entrepreneurial activities of the company. Entrepreneurial orientation related to corporate strategy, covering specific aspects of entrepreneurship and styles, methods and practices of decision making. While Jambulingan et al. (2005) defines "Entrepreneurial orientation is defined as the processes, practices and decision making activities that lead to the development and delivery of new and innovative services that can differentiate an organization from other is its market".

Based on the definition put forward by Miller (1993), some researchers have agreed that entrepreneurial orientation is a combination of the three dimensions of innovative, proactive and risk-taking. Thus, entrepreneurial orientation include the desire to innovate the market supply, taking the risk to try to enter new market opportunities (Wiklund and Shepherd, 2005). Some researchers also used the definition of Miller (1993) for testing the fourth dimension that is competitive aggressiveness (Lumpkin and Dess, 2001).

Lumpkin and Dess (2001) states "entrepreneurial orientation was a multidimensional measure, and Click or call now sub-dimension had a different impact with key outcome variables", in this study Lumpkin \& Dess identified five dimensions of entrepreneurial orientation, namely: autonomy, innovative, risk taking, proactive and aggressiveness of competition.

\section{Environment Adaptability}

One of the organizational culture that is adaptability, which is the ability to make internal changes in response to the environment likely to improve performance (Denison, 1996). Therefore, the adaptability of the environment requires organizations must develop norms and beliefs that are supporting the ability to receive and then interpret as a signal that comes from the environment and translate into cognitive and behavioral changes. Study Lumpkin \& Dess (1996) explains that organizations that have demonstrated the ability of adaptation to the environment with the following indications: (1) The organization is constantly adjusting to the changes made in accordance with a feedback strategy based market (2) The process of product planning and business adjust or involved, customers, suppliers and financiers (3) organization to quickly make adjustments to environmental changes.

Study of Miles and Snow (1993) concluded that adaptability has relationship with the performance of the small-scale enterprises. Referring to the Denison organizational culture model (2001), there are four 
components of organizational culture, namely: (1) involvement, (2) Consistency, (3) Adaptability and (4) Mission.

The four organizational culture has a different effect on the effectiveness of several criteria and not all of these cultural properties have the same impact on business performance. This study proposes adaptability as one of the organizational culture that meets all the conditions laid down Barney (1989). Denison (1990) defines adaptability as "the organizational capacity to change in response to axternal condition". The results of the study Denison and Mishra (1995) found that adaptability is one of the best predictors of business performance is strongly influenced by entrepreneurship. Daft (2007) argues that if the external environment requires flexibility and responsiveness, a culture that encourages adaptability to meet the needs of stakeholders and thereby improving organizational performance. This is consistent with the phenomenon that is contained in the micro, small and medium industries chips are facing problems as a result of changes in the business performance of external environmental conditions and require high flexibility. This adaptability culture is quite appropriate as a representation of the culture of the organization to determine its impact on business performance. Research Denison (2001) will focus on the role of environmental adaptability as a source of competitive advantage, which is empirically related to business performance.

\section{Government Policy}

\section{Definition of Variable and indicator}

According to Indonesian law, Act 20 of 2008 (Chapter IV, Article 6), Government Policy is defined as a business to grow and develop SME's activities, by facilitating empowerment in the areas of capital and equipment, production and processing, marketing, human resources as well as design and technology, in response to the global financial crisis while the real sector and encouraging the use of domestic products. The government policy variables are measured through indicators: (1) Provision of capital assistance and equipment (2) Empowerment of production and processing (3) marketing Empowerment (4) empowerment of human resources.

\section{Orientation Entrepreneurship}

In this study operationally defined as the entrepreneurial orientation of decision-making styles, processes and methods that inform the activities of entrepreneurial companies. The variables measured through indicators of entrepreneurial orientation, namely Autonomy, Innovative, risk taking, and Aggressive proactive competitive advantage.

\section{Environment Adaptability}

In this study the environmental adaptability operationally defined as the mental attitude of employers chips in adjusting to external changes. The adaptability of the environment variable is measured through indicators: (1) Creation of change (2) Customer Focus (3) Focus supplier (4) Organizational learning.

\section{Business Performance}

Business performance is defined as the perception / assessment of micro small and medium entrepreneurs to sales growth, market share and competitive size for chip industry in East Java Province. The variables measured through indicators of business performance: (1) sales growth (2) Market share (3) Meassure competitive.

\section{Methodology and Data}

This study aims to empirically examine the effect of entrepreneurial orientation, and environmental adaptability of government policy on business performance. The study was called the explanatory research. This study aimed to clarify the influence of study variables (Maholtra, 1999). Analysis using descriptive analysis and Structural Equation Modeling.

\section{Population}

The study population was SME'S Chips industry in East Java, Indonesia. East Java Province as the study site because of the current SME's in Java a barometer cooperatives and SME's has considerable potential as a driver of the economy and society, including the largest in Indonesia. (Disperindag East Java Province, 2013). SME's criteria studied were: (1) Stand-alone and not subsidiaries or branches of companies owned, controlled or affiliated directly or indirectly with a great effort. (2) Have a business that is still productive and growing. (3) Having a good small-scale enterprises and capital, labor and market orientation. (4) Never received capital assistance and equipment to improve the business.

Based on the four criteria, the results of a survey on the number of SME's that are still active in business until now in the province of East Java amounted to 394 pieces, presented in Table 1: 
Table 1. Population SME's Craft Chips Classified by Type of Business

\begin{tabular}{|c|c|c|c|}
\hline No & District/Municipal & Number & Type of Business \\
\hline 1 & Kota Malang & 104 entrepreuners & tempe Industry \\
\hline 2 & Kabupaten Lumajang & 110 entrepreuners & pisang Industry \\
\hline 3 & Kabupaten Pasuruan & 91 entrepreuners & gadung Industry \\
\hline \multirow[t]{2}{*}{4} & Kabupaten Trenggalek & 89 entrepreuners & tempe Industry \\
\hline & Total population & 394 entrepreuners & \\
\hline
\end{tabular}

\section{Sampling}

Determination of the size and number of representative samples in this study that can be considered representative of the population by considering Slovin formula (Umar, 2002): $\mathrm{n}=\mathrm{N} /\left(1+\mathrm{Ne}^{2}\right)$

Note:

$\mathrm{n}=$ sample size

$\mathrm{N}=$ Size of population

$\mathrm{e}=$ Percent leeway inaccuracy due to sample error that can be tolerated by 0.05 .

Result:

$$
1+(394)(0,05)^{2}=\quad=198 \text { (number of sample) }
$$

Table 2. Number of samples SME's

\begin{tabular}{|c|c|c|c|}
\hline No & District/Municipal & Number of Sample & Type of Business \\
\hline 1 & Malang City & 52 entrepreneurs & tempe Industry \\
\hline 2 & Limajang & 55 entrepreneurs & pisang Industry \\
\hline 3 & Pasuruan & 46 entrepreneurs & gadung Industry \\
\hline 4 & Trenggalek & 44 entrepreneurs & tempe Industry \\
\hline 5 & Total sample & 198 entrepreneurs & \\
\hline
\end{tabular}

\section{Result}

The questionnaire was distributed to 198 respondents. For five months, the data collected and carried tabulation and analysis. The evaluation results prove that the questionnaire item questionnaire respondents understood the level of validity and reliability are good. Statistics were generated for the product moment correlation value exceeds the cut-off (0.6), so does the value of Chronbach alpha $(0.747)$ exceeds the cut-off correlation value $(0.138)$

The results of the analysis of the description described by the mean value of the indicator study are presented in Table 3:

Table 3. Description of Indicators Research

\begin{tabular}{|c|c|c|c|c|}
\hline Variable & Indi & & Mean & Factor Loading \\
\hline \multirow{4}{*}{ WISE $=$ Policy } & PB & $=$ the government provision of capital and equipment & 4,23 & 0,86 \\
\hline & PR & $=$ empowerment of production and processing & 3,86 & 0,85 \\
\hline & $\mathrm{PP}$ & $=$ empowerment marketing & 4,02 & 0,82 \\
\hline & PS & $=$ empowerment of human resources & 4,27 & 0,87 \\
\hline \multirow{5}{*}{$\begin{array}{l}\text { KWRS } \\
\text { Orientation Entrepreneurship }\end{array}$} & OT & $=$ otonomy & 3,97 & 0,97 \\
\hline & KN & $=$ inovation & 4,39 & 0,88 \\
\hline & $\mathrm{RS}$ & $=$ taking risk & 4,12 & 0,86 \\
\hline & KF & $=$ proactive & 4,15 & 0,84 \\
\hline & $\mathrm{AB}$ & $=$ aggressive Competitive & 3,85 & 0,98 \\
\hline \multirow{4}{*}{$\begin{array}{l}\text { ADAP }= \\
\text { Adaptability Environmental }\end{array}$} & $\mathrm{PH}$ & $=$ change & 4,27 & 0,83 \\
\hline & FP & $=$ costomer focus & 4,43 & 0,87 \\
\hline & FK & $=$ suplyer focus & 4,09 & 0,85 \\
\hline & $\mathrm{PO}$ & $=$ organization learning & 4,52 & 0,78 \\
\hline \multirow{3}{*}{$\begin{array}{l}\text { Kinja } \\
\text { Business Performance }\end{array}$} & $\mathrm{PN}$ & $=$ sales growth & 3,90 & 0,92 \\
\hline & $\mathrm{PA}$ & $=$ market share & 4,18 & 0,96 \\
\hline & UK & $=$ competetive measure & 4,26 & 0,84 \\
\hline
\end{tabular}

Government policy is expressed on human empowerment efforts that empower entrepreneurs, entrepreneurial orientation is expressed by the degree of aggressiveness of SME's in competition, environmental adaptability to SME's more prominent high level of attention to the customer means that SME's prefer to focus on the customer to meet market demand. SME's business performance is indicated by the level of sales growth. Structural Equation Modeling analysis results are shown in Figure 1: 


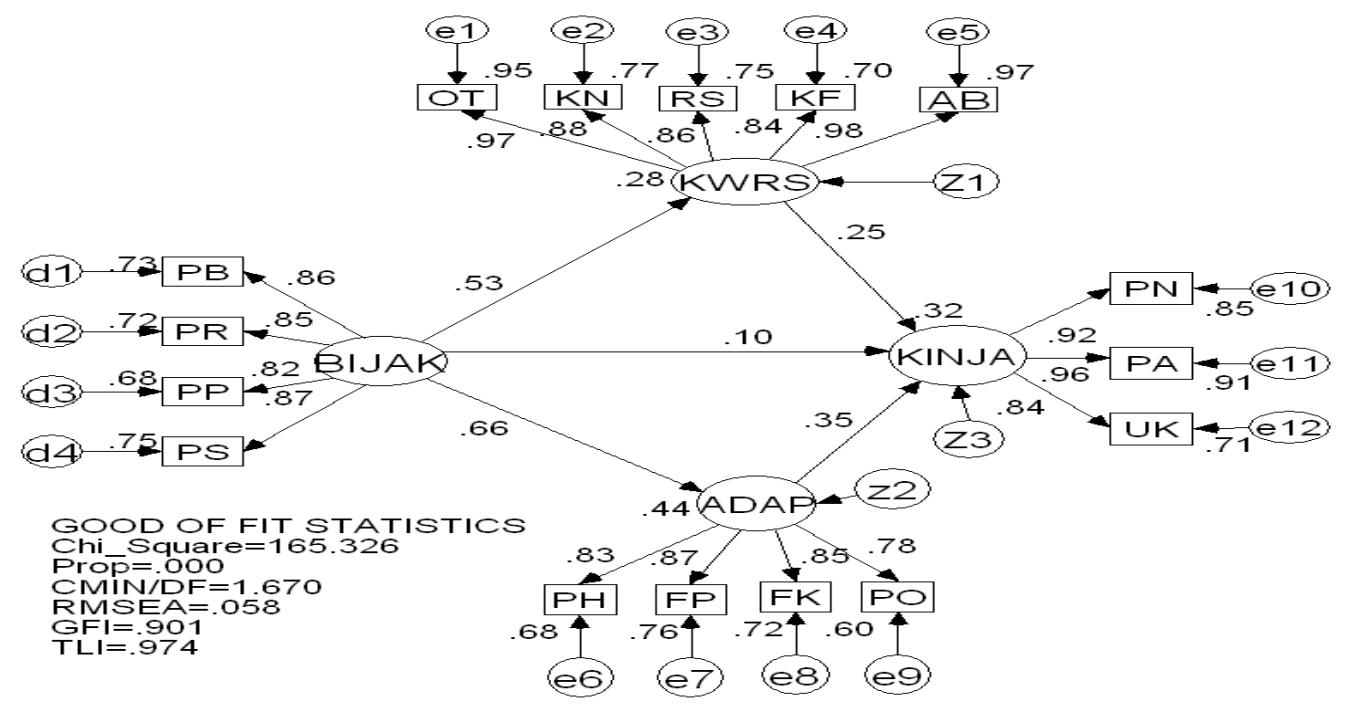

Figure1. Structural Equation Modeling

The results of modeling are built researchers can be used as an analytical tool. Chi_Square value divided by 1.670 Degree of freedom is less than the cut-off (2). RMSEA value of 0.58 is less than the cut-off value (0.08). Structural equation models were built researchers were able to reflect the real conditions on the object under study. The results of the research analyst paths between variables appear In table 4:

Table 4. Analysis of the direct path of study variables

\begin{tabular}{|c|c|c|c|c|c|}
\hline exogenous & mediation & endogenous & Direct effect & Indirect effect & Total effect \\
\hline $\begin{array}{l}\text { Goverment } \\
\text { regulated }\end{array}$ & & $\begin{array}{l}\text { Business } \\
\text { Performance }\end{array}$ & 0,1 & 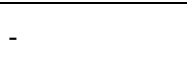 & 0,1 \\
\hline $\begin{array}{l}\text { Goverment } \\
\text { regulated }\end{array}$ & $\begin{array}{l}\text { Enterpreuner } \\
\text { Oriented }\end{array}$ & $\begin{array}{l}\text { Business } \\
\text { Performance }\end{array}$ & 0,1 & $0,13 *$ & $0,23 *$ \\
\hline $\begin{array}{l}\text { Goverment } \\
\text { regulated }\end{array}$ & $\begin{array}{l}\text { Environment } \\
\text { Adaptability }\end{array}$ & $\begin{array}{l}\text { Business } \\
\text { Performance }\end{array}$ & 0,1 & $0,23^{*}$ & $0,33 *$ \\
\hline
\end{tabular}

The results of the evaluation of Table 4, show that environmental adaptability capable of being a good mediation compared with entrepreneurial orientation, as evidenced by the value of the indirect effect of 0.23 is greater than 0.13

\section{Finding}

The research proves that the implementation of government policies have not been able to directly improve business performance. The main factors that cause is government policy is still focused on improving entrepreneurial skills and have the aspect of market demand, so it can not directly improve the SME's business performance. The government has provided assistance in the capital, ease of licensing, training and ongoing mentoring to improve business performance.

Entrepreneurship has a great authority on the operation of the business field. Entrepreneurial free to determine the direction of the business to make a profit. So that the autonomy of entrepreneurship has an important role to develop the business. The test results have proved that the policy orientation in developing a business venture is able to improve the performance of enterprises SME's. Therefore, the motivation like self-confidence, openness and a more vigorous effort is needed for SME's to achieve success in order to increase sales, expand market share and improve profit growth.

In addition, the ability of entrepreneurial adaptability to the customer is able to improve the performance of enterprises SME's. The test results prove that the government's policy is capable of creating an entrepreneurial environment adaptability in particular to customers and eventually have an impact on improving the business performance of SME's. The government has empowered human resources through education and workforce training to be able to improve the adaptability of the environment to better focus on the customer so that SME's easier to increase market share.

\section{Notes On First Contributor}

Samiaji is a lecturer at the Faculty of Economics at the University Wisnuwardhana, Malang, East Java, Indonesia. 


\section{References}

[1]. Badan Pusat Statistik Propinsi Jawa Timur, Hasil Sensus Ekonomi Jawa Timur, 2012.

[2]. Barney, J., Organizational culture : can it be a source of sustained competitive advantage, Aced. Manag. Rev. 11,1989 : $656-665$.

[3]. Daft RI, Organization Theory and Design $\left(9^{\text {th }}\right.$ Ed.) Cincinati. Oh : South-Western, 2007.

[4]. Denison, D.R. Corporate Culture and Organization Effectiveness, Wiley, New York, 1990.

[5]. Denison, D.R. and Mishra, A.K. Toward a Theory of Organizational Culture and Market Orientation : Comparing Indian and Japanese Firms, Journal of International Marketing 7(4),1995 : 111-112.

[6]. Denison, D.R. Diagnosing Organizational Cultures : Validating A Model and Method,2006.

[7]. Dinas Perindustrian dan perdagangan Propinsi Jawa Timur, Daftar Sentra Industri dan perajin keripik Propinsi Jawa Timur tahun 2013.

[8]. Farrel, Business Management and External Environment, paper for academic of Management Annual Meeting, pp.1992: 31-39

[9]. Hidayatullah., Peranan Adaptabilitas, Orientasi Kewirausahaan dan Inovasi dalam meningkatkan Kinerja Usaha Mikro (Studi pada industri Kerajinan Rotan di Kalimantan Selatan), Disertasi Unibraw, Malang,2011.

[10]. Jacobson, D., and Andreosso B. Industrial Economics and Organization : A European Perspective, Mcgraw-Hill,1996

[11]. Jambulingam, T., Kathuria, R., and Doucette, W. Entrepreneurial Orientation as a Basis for Classification within a Service Industry : The Case of Retail Pharmacy Industry. Journal of Operations Management 23, $2005: 23-42$.

[12]. Kroon and P.L. Moolmann, 1992. Entrepreneurship. Potchefstroom, South Africa : Central Publication, Potshefstroom Univercity for Christian Higher Education,1992.

[13]. Laceiva. M. Rural Entrepreneurship Success Determinant. Paper. Faculty of Economic. Latvian University of Agriculture. Eksjo. Latvian,2004.

[14]. Lumpkin, G.T. and Dess, G.G. Clarifying The Entrepreneurial Orientation Construct and Linking it to Performance, Academy of Management Review, 21 (1) $1996: 135-172$.

[15]. Lumpkin, G.T., and Dess, G.G. Linking Two Dimensions of Entrepreneurial Orientation to Firm Performance : The Moderating Role of Environment and Industry cycle, Journal of Business Venturing 16,2001: 429-451.

[16]. Malhotra, N.K., Marketing Research: An Applied Orientation, $2{ }^{\text {nd }}$ Prentice-Hall Inc., New Jersey,1999.

[17]. Miller, D., and P.H. Friesen. 1993. Organizations : A Quantum View. New York: Prentice- Hall,1993.

[18]. Miles E Raymond, Miles Grant, Snow C Charles, Collaborate Entrepreneurship : A Business Model For Continuous Innovation Organizational Dynamics, Journal, Vo. 35, No.1,1993, pp.1-11.

[19]. Porter M., Competitive Strategy, Collier Macmillan,1997.

[20]. Rante, Yohanes, Pengaruh budaya, peran pemerintah dan perilaku kewirausahaan terhadap kinerja usaha mikro kecil agribisnis di Propinsi Papua, Disertasi Unibraw, Malang, 2011

[21]. Respati, Harianto., Surachman., Djumilah Hadiwidjojo., \& Djumahir, A Mediating Factor of Consumer Trust in ISO 9000 Implementation in Relation to Customer Satisfaction: A Study on Internal Perceptions of Indonesian Manufacturing Companies, Journal of Business and Management, Vol.7, pp 50-56. 2013. DOI: 10.9790/487X-0755056

[22]. Tambunan, Tulus, Usaha Mikro Kecil Dan Menengah di Indonesia : Beberapa Isu Penting, Penerbit LP3ES, Cetakan Pertama, Jakarta,2012.

[23]. Umar, Husein. Metode Riset Bisnis : Dilengkapi Contoh Proposal dan Hasil Riset Bidang Manajemen dan Akuntansi, Penerbit PT.Gramedia Pustaka Utama, Jakarta,2002.

[24]. Undang-undang Republik Indonesia No. 20 tahun 2008 Bab IV, Pasal 6 tentang Usaha Mikro, Kecil dan Menengah,2008.

[25]. Westhead, P and D Story, Management Training and Small firm Performance : Why is link So Weak International Small Business Management, Vo. 30, No. 2, p 39, 1996.

[26]. Wiklund, J. and Shephered. The Sustainability of the Entrepreneurial Orientation-Performance Relationship, Entrepreneurship Theory and Practice Journal 24, $2005: 37-48$. 